\title{
DROSERA BICOLOR LOWRIE \& CARLQUist
}

\author{
Robert Gibson • 5 Kristen Close • Cardiff Heights • NSW, $2285 \cdot$ Australia • robert.gibson@, \\ environment.nsw.gov.au
}

Keywords: taxonomy: Drosera bicolor.

Drosera bicolor Lowrie \& Carlquist is endemic to southwestern Australia (Lowrie \& Carlquist 1992). It is an erect tuberous sundew with alternate leaves and a basal rosette, placed in Drosera subgenus Ergaleium section Ergaleium. Prior to its formal description this species was informally known as 'D. peltata 'Hammersley". Since its description, debate has continued as to whether it is a distinct taxon or is better treated in the broader concept of Drosera peltata Thunb (e.g. Lowrie \& Carlquist 1992; Schlauer 2012). This paper presents a more detailed description of this taxon and discusses its taxonomic status.

Drosera bicolor grows in the sandplains of the Upper Phillips River about $35 \mathrm{~km}$ northwest from Ravensthorpe (Lowrie 1998; FloraBase 2012). It grows in gaps between shrubs in a low, open shrubland, and appears to be most common in small shallow depressions fringed by various species of restiads (Restionaceae) (Fig. 1(a)). It often grows in the company of D. zonaria Planch. The growing medium is deep pale brown fine-grained quartz sand that develops a brittle surface crust. So far this species is only known from its type location, but it is likely to occur more widely throughout this area in the same habitat.

The general habit of D. bicolor has a flat basal rosette of leaves from which an erect stem with alternate crescentic petiolate leaves, with a peltate attachment of the petiole, and flowers arranged in a one-sided scorpioid cyme (Fig. 1(a)). This growth habitat is typical of members of the D. peltata complex (Gibson et al. 2012). Drosera bicolor has a calyx with sepals that bear glandular hairs on the margin and outer surface (Fig. 1(e)), and ovoid seeds with a shallowly pitted reticulate surface texture that are up to $0.3 \mathrm{~mm}$ long (Fig. 1(h)) which may explain why D. bicolor was initially considered to represent a strange form of $D$. peltata.

However, Drosera bicolor was described as a separate species due to the following characters: the red patch of pigment at the base of each otherwise white petal (Fig. 1(e)), the style segments arranged in a flat rosette (Fig. 1(f,g)), cauline leaves that increase in size towards the stem apex (Fig. 1(c,d)), and the lengthening and changing orientation of the petioles (from stem-appressed to spreading) of successive cauline leaves (Lowrie \& Carlquist 1992; Lowrie 1998). These characters are not found in any members of the $D$. peltata complex, including the superficially similar $D$. yilgarnensis R.P. Gibson \& B.J. Conn (previously 'D. peltata 'Western Australian Form” sensu Lowrie (1987; pp. 88-91)).

Close examination of $D$. bicolor plants has revealed some other unique characters to the cauline leaves that pertain to the gradual change in leaf size and shape, and in the point of attachment of the petiole to the leaf blade in successively produced leaves. Mature plants of $D$. bicolor produce an erect stem between 5 and $20 \mathrm{~cm}$ tall with between about 9 and 15 cauline leaves. Stem internode length varies between successive leaves, and is between about 2 and $4 \mathrm{~mm}$ long in the lower part of the stem; between about 5 and $10 \mathrm{~mm}$ between the middle leaves, and up to $15 \mathrm{~mm}$ long between the uppermost leaves. 

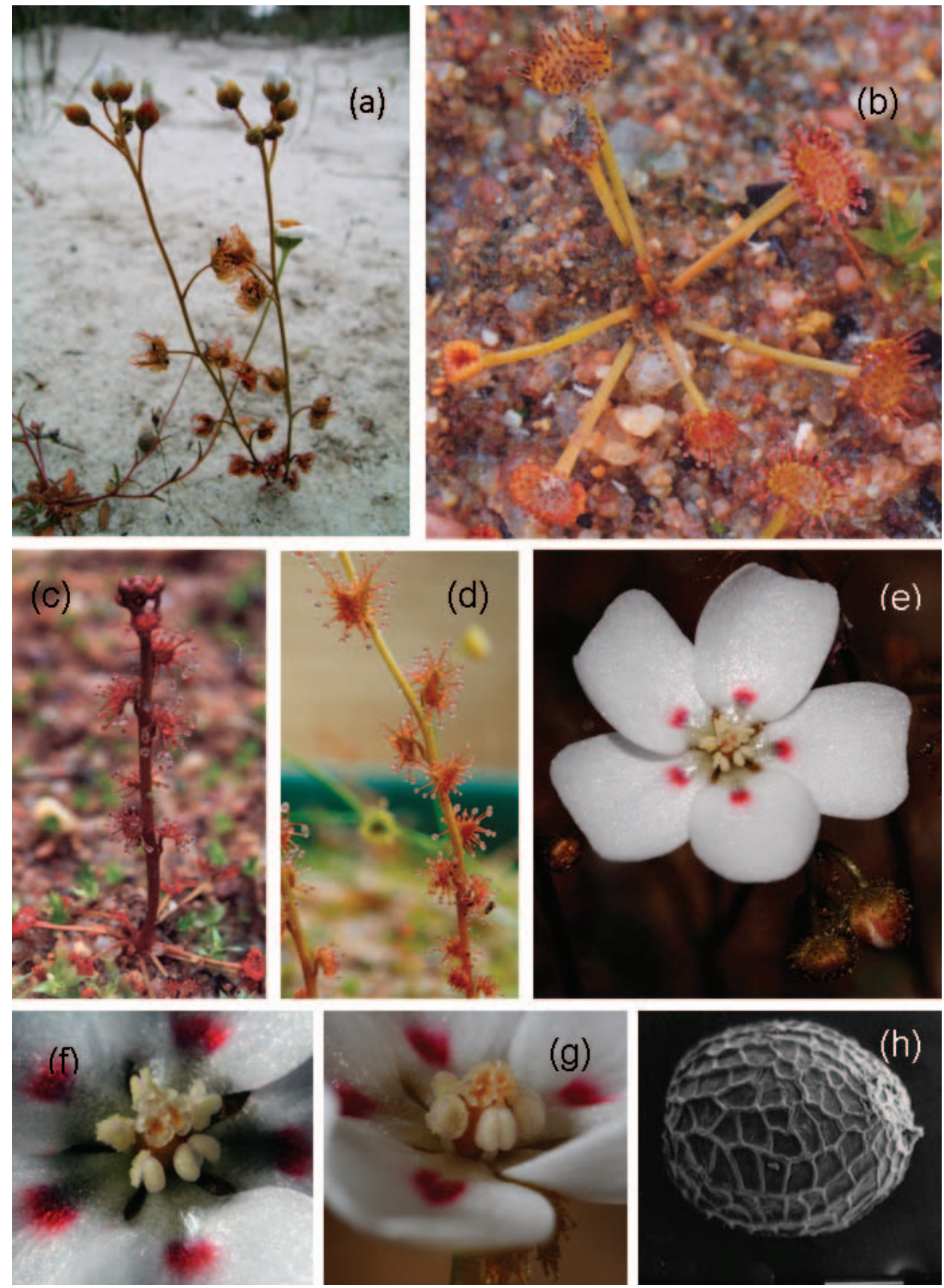

Figure 1: Photomosaic of Drosera bicolor: (a) mature plants in bud in the wild; (b) developing rosette of a plant in cultivation; (c) cultivated plant with small lower stem leaves; (d) cultivated plant with maturing stems with noticeably larger leaves towards the stem apex; (e) open flower with distinctive bicolored petals; ( $f$ ) ovary and styles from above; ( $g$ ) oblique view of the flower structure showing the short stamens; and (h) SEM of a D. bicolor seed (R. Gibson 028, NSW), scale bar is $0.1 \mathrm{~mm}$ long. All photos but (h) by R. Gibson; photo (h) by P. Littlefield. 
The lowermost cauline leaves are broadly obovate in shape, to $2 \mathrm{~mm}$ wide by $1.5 \mathrm{~mm}$ long with a flat upper margin. Petioles are about 1 to $1.5 \mathrm{~mm}$ long, attached to the midpoint of the leaf upper margin (Fig. 1(c)). Successive leaves increase marginally in size, so they are about $2 \mathrm{~mm}$ wide by $2 \mathrm{~mm}$ long, and the upper leaf margin becomes emarginate so that the middle leaves are crescentic in shape. Petioles are between about 2 and $4 \mathrm{~mm}$ long and are attached on the mid-point of the upper leaf margin (Fig. 1(d)). Leaves in the upper third of the stem are up to $2.5 \mathrm{~mm}$ wide by $2 \mathrm{~mm}$ long with a deeply emarginate upper leaf margin. Petioles are 4 to $7 \mathrm{~mm}$ long and now have a peltate attachment to the back of the lamina (Fig. 1(d)). The upper leaves also have horn-like extensions of the upper corners of the lamina, or auricules; that in this species can be up to $3.5 \mathrm{~mm}$ long (Lowrie 1998). In addition to the unique style architecture this species also has remarkably short filaments so that the stamens are shorter than the gynoecium (Figs. 1(e-g)).

The curious gradual variation in the size of the cauline lamina and the length of the cauline leaf petiole in $D$. bicolor is only found in three other Australian sundews: remarkably only one of these is another tuberous sundew: D. menziesii R.Br. ex DC. subsp. basifolia N.G.Marchant \& Lowrie (Lowrie 1998). The other two species, D. banksii R.Br. ex DC. and D. subtilis N.G.Marchant (Lowrie 1998), are annual species from northern tropical Australia, the former has been placed in Drosera subgenus Lasiocephala (Rivadavia et al. 2003). The shared leaf characters between these two distantly-related pairs of species suggest that this may be an example of convergent evolution. There may be a number of factors favoring this unusual change in cauline leaves, these hypotheses include: (1) the close-pressed leaves at the base of the stem form a barrier to some walking (or crawling) herbivores that may otherwise eat the new stem growth; (2) the lower leaves capture small ground-dwelling and flying prey, such as springtails (Collembola) and fungus gnats (Diptera), while the upper cauline leaves are dedicated to capture (larger) flying insects; (3) these sundews may initially grow faster than sympatric herbs but then start to be shaded by them, thus leaf shape size variation reflects the most efficient allocation of resources to plant parts; and (4) the initial stem growth is acting as a small target to reduce the chance of browsing kangaroos and wallabies in taxa that may lack other means of defense (such as bad-tasting compounds). When a plant is browsed new stem growth can develop from the remaining stem portion but this secondary growth may not flower, or produce fewer flowers than an undamaged plant and thus produce less seed in that growing season. It would be interesting to run some experiments and make further field observations to test these hypotheses, and develop other ideas that may explain this marvelous leaf pattern.

The overall plant structure of a basal rosette with a central stem with alternate leaves that include some that are crescentic and some that are peltate and flowers borne in a terminal inflorescence with hairy sepals is reminiscent of plants in the D. peltata complex. However the disc-like styles, stamens shorter than the gynoecium, petals with a red basal blotch, and cauline leaves with a gradual change in size, shape, petiole length, and petiole attachment are not found in any members of the $D$. peltata complex. Therefore, based on this investigation $D$. bicolor is considered to be a distinctive species that is not part of the D. peltata complex.

Acknowledgements: Thanks to Mr. Phill Mann for his assistance with fieldwork and many excellent discussions about this species. Thanks also to Mr. Patrick Littlefield (UNE) for his assistance in producing the SEM image used in this paper. The author gratefully acknowledges funding from a Noel C. W. Beadle Scholarship (UNE) that helped fund the use of the SEM microscope. I also wish to thank anonymous reviewers for their helpful comments that improved this paper. 
References

FloraBase 2012. Drosera bicolor. http://florabase.dec.wa.gov.au/browse/profile/13386 [viewed 28 May 2012].

Gibson, R., Conn, B.J., and Bruhl, J.J. 2012. Morphological evaluation of the Drosera peltata complex (Droseraceae). Australian Systematic Botany 25: 49-80.

Lowrie, A. 1987. Carnivorous Plants of Australia: Vol. 1. University of Western Australia Press, Nedlands.

Lowrie, A. 1989. Carnivorous Plants of Australia: Vol. 2. University of Western Australia Press, Nedlands.

Lowrie, A. 1998. Carnivorous Plants of Australia: Vol. 3. University of Western Australia Press,

Nedlands.

Lowrie, A. and Carlquist, S. 1992. Eight new taxa of Drosera from Australia. Phytologia 73: 98-116. Rivadavia, F., Kondo, K., Kato, M., and Hasebe, M. 2003. Phylogeny of the sundews, Drosera (Droseraceae), based on chloroplast $r b c L$ and nuclear $18 \mathrm{~S}$ ribosomal DNA Sequences. American Journal of Botany 90(1): 123-130.

Schlauer, J. 2012. Carnivorous Plant Names Database. http://www.carnivorousplants.org/cpdb/

SearchCPdb.php [viewed 21 Sept. 2012]

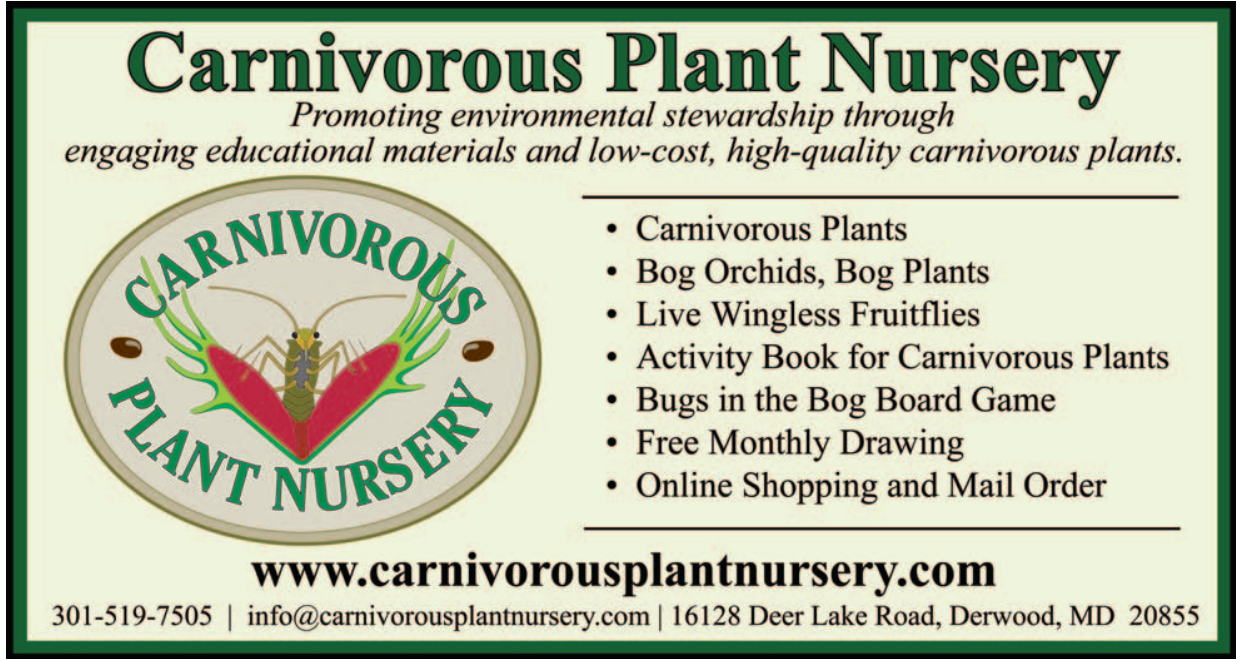

\section{Ferocious Foliage.com Custom Tissue Culture Laboratory}

* In vitro propagation of plants from material you provide

* Cloning and mass production

* Induced polyploidy, gibberellic acid and smoke water treatment

* Custom rooting of Nepenthes (your plants or our stock)

Why would you want these services?

* For very difficult species, have a lot of individuals to experiment with

* Propagate unique clones to share or sell

* Decrease risk of germination failure, especially if you have few seeds 